\title{
Review of ER:YAG Laser-Assisted Pulpotomy in Primary Dentition
}

\author{
Maria Shindova ${ }^{1}$, Ani Belcheva ${ }^{1}$
}

\begin{abstract}
The endodontic infection of primary teeth is the infection of the root canal system and can involve the pulp as well as the periapical tissues surrounding the apex of the tooth root. The main goal is to maintain the integrity and health of the primary tooth until their physiological exfoliation. Pulpotomy is the most commonly used method for endodontic treatment of deciduous dentition. Knowledge of the alternative pulpotomy techniques is a useful advantage of dentists to meet the functional problems associated with endodontic infection in very young and anxious patients. The aim of this article is to systematically review the contemporary scientific literature concerning the effect of Er:YAG laser technology in the pulpotomy of primary teeth. A critical evaluation of the various parameters for laser ablation and unconvincing results has been made. The expository analysis summarizes the succession of this therapeutic approach. Future studies should also seek and compare the long-term effects of the use of traditional and alternative pulpotomy techniques.
\end{abstract}

Keywords: Pulpotomy, Er:YAG laser, Primary dentition, Pediatric dentistry

\section{Introduction}

The endodontic infection of primary teeth is the infection of the root canal system and can involve the pulp as well as the periapical tissues surrounding the apex of the tooth root. In these cases, there are two treatment options - pulpotomy and pulpectomy. Pulpotomy is a treatment method including removal of the coronal

\footnotetext{
${ }^{1}$ Department of Pediatric Dentistry, Faculty of Dental Medicine, Medical University - Plovdiv, Bulgaria

* Corresponding Author

Maria Shindova mariya.shindova@gmail.com, mariya.shindova@mu-plovdiv.bg ORCID: 00000003-2996-3700
}

* Received: 10 May 2021 Accepted: 18 June 2021

DOI: 10.17932/EJOH.2020.022/ejoh_v02i1007 
pulp (vital or mortal amputation) and preservation of the radicular pulp treated with a pulpotomy medicament to maintain its vitality or to transform it into an aseptic bundle, which is like plastic (1). The other treatment method, pulpectomy, represents a complete removal of necrotic and irreversibly infected pulp tissue of the pulp chamber and root canals of a tooth affected by extensive caries lesions, traumatic injuries or other causes $(2,3)$. The main goal of endodontic treatment of primary teeth is to maintain the integrity and health of the primary tooth until their physiological exfoliation (4). As the tooth remains asymptomatic, in anatomical and functional conditions, it performs an extremely important role in the masticatory process and has phonetic, aesthetic and morphological functions $(2,4)$.

Pulpotomy is the most commonly used method for endodontic treatment of deciduous dentition (1). Several important and essential elements in pulpotomy as a pulp therapy are required - adequate debridement of the infected coronal pulp tissue and antimicrobial activity of the irrigants and medicaments, sufficient hemostasis and no thermal affection of the remaining pulp and surrounding tissues. Owing to the properties of Er:YAG lasers, they can be used as an alternative to the 'gold standard', i.e., formocresol, for pulpotomy in primary teeth. This laser family has hemostatic and antimicrobial effect as well as causes no or slight thermal alterations of the surrounding tissues and the underlying radicular pulp $(5,6,7,8)$.

Few studies described the results of Er:YAG laser-assisted pulpotomy in primary teeth. Due to the numerous advantages of Er:YAG lasers, modern pediatric dentistry involves their use in routine daily practice $(9,10,11)$. In addition, pulpal diseases in primary dentition are a common dental problem (1). Thus, the aim of this article is to systematically review the contemporary scientific literature concerning the effect of Er:YAG laser technology in the pulpotomy of primary teeth. A critical evaluation of the various parameters for laser ablation and unconvincing results has been made. The expository analysis summarizes the succession of this therapeutic approach (Table 1). 
Table 1. Overview of the Er:YAG pulpotomy studies

\begin{tabular}{|c|c|c|c|c|c|c|c|c|}
\hline Authors & $\begin{array}{c}\text { Year of } \\
\text { publication }\end{array}$ & Country & $\begin{array}{l}\text { Type of } \\
\text { article }\end{array}$ & $\begin{array}{c}\text { Average } \\
\text { pulse- } \\
\text { energy }\end{array}$ & $\mathrm{Hz}$ & $\begin{array}{l}\text { irra- } \\
\text { dia- } \\
\text { tion } \\
\text { time }\end{array}$ & $\begin{array}{l}\text { Water } \\
\text { spray }\end{array}$ & $\begin{array}{c}\text { Material } \\
\text { used after } \\
\text { Er:YAG } \\
\text { laser } \\
\text { pulpotomy }\end{array}$ \\
\hline $\begin{array}{c}\text { Jayawardena } \\
\text { et al. }\end{array}$ & 2001 & Japan & $\begin{array}{l}\text { Experimental } \\
\text { animal study }\end{array}$ & $\begin{array}{c}150 \mathrm{~mJ} / \\
\text { pulse }\end{array}$ & 10 & $\mathrm{n} / \mathrm{a}$ & + & $\begin{array}{l}\text { Sterile saline } \\
\text { solution }\end{array}$ \\
\hline Kimura et al. & 2003 & Japan & $\begin{array}{l}\text { Experimental } \\
\text { animal study }\end{array}$ & $34 \mathrm{~mJ} /$ pulse & $\mathrm{n} / \mathrm{a}$ & $15 \mathrm{~s}$ & $\mathrm{n} / \mathrm{a}$ & $\mathrm{n} / \mathrm{a}$ \\
\hline $\begin{array}{c}\text { Huth KC } \\
\text { et al. }\end{array}$ & 2005 & Germany & Clinical trial & $\begin{array}{c}180 \mathrm{~mJ} / \\
\text { pulse }\end{array}$ & 2 & $\mathrm{n} / \mathrm{a}$ & - & $\begin{array}{c}\text { Formocresol- } \\
\text { moistened } \\
\text { pellets for } 5 \\
\text { minutes }\end{array}$ \\
\hline Olivi et al & 2007 & Italy & Clinical trial & $\begin{array}{c}75-100 \mathrm{~mJ} / \\
\text { pulse }\end{array}$ & 3 & $60 \mathrm{~s}$ & + & $\begin{array}{l}\text { Immediately } \\
\text { filled with } \\
\text { adhesive } \\
\text { systems: } \\
\text { a flowable } \\
\text { composite }\end{array}$ \\
\hline Kotlow et al. & 2008 & USA & Clinical case & $55 \mathrm{~mJ} / \mathrm{pulse}$ & 30 & $\begin{array}{c}15 \mathrm{~s}, \\
3 \\
\text { times }\end{array}$ & + & $\begin{array}{l}\text { Zinc oxide } \\
\text { eugenol } \\
\text { cement } \\
\text { and the } \\
\text { appropriate } \\
\text { restoration }\end{array}$ \\
\hline $\begin{array}{l}\text { Hasheminia } \\
\text { et al. }\end{array}$ & 2010 & Iran & $\begin{array}{l}\text { Experimental } \\
\text { animal study }\end{array}$ & $\begin{array}{c}200 \mathrm{~mJ} / \\
\text { pulse }\end{array}$ & 3 & $15 \mathrm{~s}$ & - & MTA \\
\hline $\begin{array}{c}\text { Huth KC } \\
\text { et al. }\end{array}$ & 2011 & Germany & Clinical trial & $\begin{array}{c}120 \mathrm{~mJ} / \\
\text { pulse }\end{array}$ & 2 & $\mathrm{n} / \mathrm{a}$ & - & $\begin{array}{c}\text { Ferric } \\
\text { sulphate- } \\
\text { wetted pellets } \\
\text { for } 15 \mathrm{~s}\end{array}$ \\
\hline
\end{tabular}

$*_{\mathrm{n}} / \mathrm{a}$ - not applicable 
In an experimental animal study, Kimura et al. found that the effects of the Er:YAG laser irradiation on pulp tissues during a pulpotomy are minimal. The authors reported no inflammation or resorption in the investigated rat molars when $34 \mathrm{~mJ} /$ pulse for 15 seconds was used. As a result of the laser irradiation, there was no bleeding after coronal pulp removal (6). As a result of other animal studies, the researchers concluded that the investigated parameters for laser irradiation were not recommended for the treatment of human teeth in clinical settings $(7,12)$. However, other authors stated that if appropriate parameters were used, the application of Er:YAG laser is a treatment option for pulpotomy in primary teeth (6).

As to the effect of Er:YAG laser on the pulp tissue bleeding, Olivi et al. pointed out as a disadvantage of Er:YAG laser the lack of complete hemostasis due to the minimal thermal effect of the surrounding tissues (13). However, the authors reported an easier control of bleeding after laser irradiation compared to the conventional treatment procedures (13). In 2015, Nazemisalman et al. confirmed the data obtained by Olivi et al. They found favorable results after 2 years of follow-up investigating the pulp coagulation effect of Er:YAG laser (14). Keller et al. reported a 3-6 minutes duration about the reduction of pulp microcirculation after Er:YAG laser irradiation as well as no hyperemic actions $(8,15)$.

In a long-term study, Huth et al. investigated the effectiveness of Er:YAG laser in pulpotomy of primary teeth $(8,15)$. After 36 months, the authors reported $73 \%$ success rates which are comparable to those of the application of 'gold standard' (formocresol) $-72 \%$, and ferric sulfate - 76\%. The follow-up included clinical and radiograph examinations. The parameter settings used were

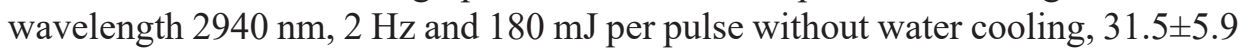
mean number of laser pulses per tooth. No significant differences in total success rates between the different pulpotomy techniques were found $(8,15)$.

Kotlow et al. presented a protocol for performing Er:YAG laser-assisted pulpotomy in deciduous teeth. The authors described a series of clinical cases of endodontic treatment in primary molars using laser technology (16). The successful results, clinical and paraclinical, confirmed the effectiveness of Er:YAG laser in pulp therapy of primary teeth as an alternative to the chemical agents or electrosurgery. The teeth from the presented clinical cases were irradiated with Er:YAG laser (HOYA ConBio`s DELight) emission wavelength $2940 \mathrm{~nm}$, three times for 15 seconds. The parameter settings used were $30 \mathrm{~Hz}$ and $55 \mathrm{~mJ}, 20 \mathrm{cc}$ per minute water spray, average power 1.65 watts. In the study, the sapphire tip size used was $600-\mu \mathrm{m}$ in a 90-degree handpiece. In contrast, Huth et al. described the use of a special handpiece (KEY Laser 1242; handpiece 2051, KaVo, Biberach, Germany), (15). 
In a systematic review, Coster et al. analyzed seven articles and indicated the need for future studies about laser-assisted pulpotomy in order to formulate general recommendations for the clinical use of Er:YAG laser in primary teeth (17). The obtained data of another systematic review and meta-analysis are in line with the results obtained by Coster et al. who found a lack of convincing results and the necessity of further investigations (18).

\section{Conclusion}

There is not enough information describing the level of effectiveness of the use of the Er:YAG laser for pulpotomy despite its importance in the pulp therapy of deciduous teeth. In few publications, the success rate reported was the same as that of formocresol and ferric sulfate. Thus, this technology can be used successfully as a safe alternative to conventional pulp therapy agents. However, if Er:YAG laser is not part of the routine clinical setup and dental equipment, it would be difficult for general dental practitioners to implement this technology for endodontic treatment of primary teeth.

\section{References}

1. Jayaraman J, Nagendrababu V, Pulikkotil SJ, Veettil SK, Dhar V. Effectiveness of formocresol and ferric sulfate as pulpotomy material in primary molars: a systematic review and meta-analysis with trial sequential analysis of randomized clinical trials. Quintessence Int 2020;51:38-48. doi: 10.3290/j. qi.a43617. PMID: 31781690.

2. American Academy of Pediatric Dentistry. Guideline on pulp therapy for primary and young permanent teeth. Pediatr Dent 2009;31:179-86.

3. Bodrumlu E, Semiz M. Antibacterial activity of a new endodontic sealer against Entercoccus faecalis. J Can Dent Assoc 2006;72:637.

4. Antoniazzi BF, Pires CW, Bresolin CR, Weiss RN, Praetzel JR. Antimicrobial activity of different filling pastes for deciduous tooth treatment. Braz Oral Res 2015;29:1-6.

5. Schoop U, Moritz A, Kluger W, Patruta S, Goharkhay K, Sperr W,et al. The Er:YAG laser in endodontics: results of an in vitro study. Lasers Surg Med 2002;30:360-4. doi: 10.1002/lsm.10054. PMID: 12116328.

6. Kimura Y, Yonaga K, Yokoyama K, Watanabe H, Wang X, Matsumoto K. Histopathological changes in dental pulp irradiated by Er:YAG laser: a preliminary report on laser pulpotomy. J Clin Laser Med Surg 2003;21:34550. doi: 10.1089/104454703322650149. PMID: 14709218. 
7. Jayawardena JA, Kato J, Moriya K, Takagi Y. Pulpal response to exposure with Er:YAG laser. Oral Surg Oral Med Oral Pathol Oral Radiol Endod 2001;91:222-9. doi: 10.1067/moe.2001.111943. PMID: 11174601.

8. Huth KC, Hajek-Al-Khatar N, Wolf P, Ilie N, Hickel R, Paschos E. Long-term effectiveness of four pulpotomy techniques: 3-year randomised controlled trial. Clin Oral Investig 2012;16:1243-50. doi: 10.1007/s00784-011- 0602-3. Epub 2011 Aug 13. PMID: 21842145.

9. Pagano S, Lombardo G, Orso M, Abraha I, Capobianco B, Cianetti S. Lasers to prevent dental caries: a systematic review. BMJ Open 2020;10:e38638. doi: 10.1136/bmjopen-2020-038638.

10. Kumar G, Rehman F, Chaturvedy V. Soft Tissue Applications of Er,Cr:YSGG Laser in Pediatric Dentistry. Int J Clin Pediatr Dent 2017;10:188-192. doi: 10.5005/jp-journals-10005-1432.

11. American Academy of Pediatric Dentistry. Policy on the use of lasers for pediatric dental patients. The Reference Manual of Pediatric Dentistry. Chicago, Ill.: American Academy of Pediatric Dentistry 2020:116-8.

12. Komabayashi T, Ebihara A, Aoki A. The use of lasers for direct pulp capping. J Oral Sci 2015;57:277-86. doi: 10.2334/josnusd.57.277. PMID: 26666850.

13. Olivi G, Genovese MD, Maturo P, Docimo R. Pulp capping: advantages of using laser technology. Eur J Paediatr Dent 2007;8(2):89-95. PMID: 17571933.

14. Nazemisalman B, Farsadeghi M, Sokhansanj M. Types of Lasers and Their Applications in Pediatric Dentistry. J Lasers Med Sci 2015;6:96-101. doi:10.15171/jlms.2015.01.

15. Huth KC, Paschos E, Hajek-Al-Khatar N, Hollweck R, Crispin A, Hickel R, FolwacznyM.Effectiveness of 4pulpotomytechniques--randomizedcontrolled trial. J Dent Res 2005 Dec;84:1144-8. doi: 10.1177/154405910508401210. PMID: 16304444.

16. Kotlow L. Use of an Er: YAG laser for pulpotomies in vital and nonvital primary teeth. J Laser Dent 2008;16:75-9.

17. De Coster P, Rajasekharan S, Martens L. Laser-assisted pulpotomy in primary teeth: a systematic review. Int J Paediatr Dent 2013;23(6):389-99. doi: 10.1111/ipd.12014. Epub 2012 Nov 22. PMID: 23171469.

18. Lin PY, Chen HS, Wang YH, Tu YK. Primary molar pulpotomy: a systematic review and network meta-analysis. J Dent 2014 Sep;42:1060-77. doi: 10.1016/j.jdent.2014.02.001. Epub 2014 Feb 7. PMID: 24513112. 